\title{
Growth performance, nutrient intake, and microbial protein synthesis of Indonesian male sheep fed diets containing brewer residue
}

Desempenho de crescimento, ingestão de nutrientes e síntese de proteína microbiana de ovinos machos indonésios alimentados com dietas contendo resíduos de cervejaria

\author{
Wara Pratitis Sabar Suprayogi (i)* \\ Susi Dwi Widyawati (B) \\ Fajar Sari Prihatini \\ Novia Rahma Patmawati \\ Vicentius Pritto Pratecha Adi
}

Universitas Sebelas Maret (UNS), Surakarta, Indonesia

* Correspondence: warapratitis@staff.uns.ac.id

Received: 2021 Aug 15 | Approved: 2021 Sep 10

DOI: http://dx.doi.org/10.7213/acad.2021.19009

Rev. Acad. Ciênc. Anim. 2021;19:e19009

\begin{abstract}
Industrial brewing companies produce a high quantity of solid residue rich in nutrient contents that can be utilized as a feed ingredient for fattening sheep. This study aimed to evaluate the optimal proportion between rice bran and brewer residue in Indonesian local sheep. The study was designed as a completely randomized block design with a basal diet consisted of $60 \%$ forage and $40 \%$ concentrate. In total, 15 male
\end{abstract}

sheep were randomly allocated to receive one of three dietary treatments with five replicates in each (P1 $=70 \%$ rice bran $+30 \%$ brewer residue; $\mathrm{P} 2=50 \%$ rice bran $+50 \%$ brewer residue; and $\mathrm{P} 3=30 \%$ rice bran $+70 \%$ brewer residue). The parameters observed included nutrient intake, body weight gain, rumen microbial protein synthesis, and $\mathrm{NH}_{3}$ concentration. The results showed that brewer residue did not affect nutrient intakes, average daily gain (ADG), rumen $\mathrm{pH}$, and microbial protein synthesis. However, replacing rice bran with $50 \%$ and $70 \%$ (inclusion rate of $19 \%$ and $29 \%$ in the diets, respectively) of brewer residue increased dry matter digestibility and $\mathrm{NH}_{3}$ concentration in the rumen. To conclude, brewer residue can be used up to $29 \%$ to replace $70 \%$ rice bran used in the diets of Indonesian male local sheep without negatively affected sheep's performance.

Keywords: Brewer residue. Byproduct. Rice bran. Sheep. 


\section{Resumo}

A fabricação de cerveja produz uma grande quantidade de resíduo sólido rico em nutrientes que podem ser utilizados como ingrediente na dieta de ovinos de engorda. Este estudo teve como objetivo avaliar a proporção ideal entre farelo de arroz e resíduo de cervejaria em ovinos nativos da Indonésia. O estudo foi delineado em blocos inteiramente casualizados com dieta basal composta por $60 \%$ de forragem e $40 \%$ de concentrado. No total, 15 ovinos, machos, foram alocados aleatoriamente para receber um dos três tratamentos dietéticos com cinco repetições cada $(P 1=70 \%$ farelo de arroz $+30 \%$ resíduo de cervejaria; $P 2=$ $50 \%$ farelo de arroz $+50 \%$ de resíduo de cervejaria; e $P 3=$ $30 \%$ de farelo de arroz $+70 \%$ de resíduo de cervejaria). Os parâmetros observados incluíram ingestão de nutrientes, ganho de peso corporal, síntese de proteína microbiana ruminal e concentração de $\mathrm{NH}_{3}$. Os resultados mostraram que o resíduo de cervejaria não afetou a ingestão de nutrientes, o ganho médio diário (GMD), o pH ruminal e a síntese de proteína microbiana. No entanto a substituição do farelo de arroz por 50\% e 70\% (taxas de inclusão de $19 \%$ e $29 \%$ nas dietas, respectivamente) de resíduo de cervejaria aumentou a digestibilidade da matéria seca e a concentração de $\mathrm{NH}_{3}$ no rúmen. Para concluir, o resíduo de cervejaria pode ser usado em até $29 \%$ para substituir $70 \%$ do farelo de arroz usado nas dietas de ovinos nativos da Indonésia, sem afetar negativamente o desempenho dos animais.

Palavras-chave: Resíduo de cervejaria. Subproduto. Farelo de arroz. Ovino.

\section{Introduction}

A large quantity of underutilized byproducts is regularly produced from industrial manufactures, including from brewing companies. In Indonesia, the brewing industry generates nutrient-rich residue in a significant quantity. However, the high moisture content of the residue is the major constrain, making it susceptible to microbial growth that often deteriorate the material. To increase the lifespan of the material, brewing companies are now providing dried brewer residue. Given the fact that the beer residue contains a high nutritional profile, i.e., the crude protein $(\mathrm{CP})=$ $15-25 \%$, total digestible nutrient $($ TDN) $=\sim 70 \%$ (dry matter basis), and small portion minerals and phenolic compounds (Senthilkumar et al., 2010), it could be a valuable ingredient for the diet of ruminants. In particular, the use of high-quality byproducts would compensate the insufficient nutrient intake for typical Indonesian farmers that mainly depend on low-quality forages to feed their livestock (Astuti et al., 2020). Thus, providing diets with well-balanced energy and protein sources is essential to improve the growth performance of ruminants.

Several experiments have demonstrated that brewer residue could replace portions of forage neutral detergent fiber (NDF) in lactating dairy cows without adverse effects on milk production (Younker et al., 1998; Dhiman et al., 2003). Recently, brewer residue was reported to successfully replace up to $75 \%$ soybean meal in the diet with increasing effects on nutrient digestibility, milk production efficiency, as well as an economic return due to lower feeding cost (Faccenda et al., 2017). It has also been reported to be safely used in fattening lambs, which added benefit on the improvement of conjugated linoleic acids content of the meat without detrimental effects on performance and feed intake (Radzik-Rant et al., 2019). These reports indicate that brewer residue can be used in the livestock's diets to reduce the cost associated with feed and, therefore, increase farmers' income.

In Indonesia, rice bran is the most common energy source utilized for ruminants' diet; however, the availability is often scarce for ruminants because it competes with the poultry feed industry. Therefore, brewer residue can be a good alternative ingredient to replace the use of rice bran, with a possible increase in performance because it contains higher crude protein and lower fiber content. Considering that the nutritive value of beer residue varies among regions, evaluation of its use in local sheep in Indonesia should be carried out. Therefore, this study aimed to evaluate the effect of replacing rice bran with brewer residue on growth, nutrient intake, and microbial protein synthesis of Indonesian male local sheep.

\section{Material and methods}

\section{Animals and experimental design}

In total, 15 males of Indonesian local sheep (34 $\pm 2.6 \mathrm{~kg}$ ) were used in this study. All procedures 
involving animal handling on feeding and rearing management followed the principle of animal welfare ethics. The animals were kept in $1.5 \times 1.5$ $\mathrm{m}$ individual stalls equipped with feed bunks where they had free access to freshwater. The sheep were blocked according to their body weight and were distributed to three dietary treatments (five animals each).

The treatments were based on rice bran and brewer residue proportions ( $\mathrm{P} 1=70 \%$ rice bran $+30 \%$ brewer residue; $\mathrm{P} 2=50 \%$ rice bran $+50 \%$ brewer residue; $\mathrm{P} 3=50 \%$ rice bran $+50 \%$ brewer residue). The chemical composition of each ingredient and nutritional profile of experimental diets are provided in Tables 1 and 2, respectively.
The brewer residue used in this study was purchased from a local brewing industry in Surakarta, Indonesia. The wet residue was formulated for experimental animals as total mixed rations (TMR). The experimental periods lasted 60 days, comprising 30 days of adaptation period and followed by 30 days sampling period. During these periods, the animals were fed ad libitum twice a day at 8 am and 3 pm with the amount to achieve $10 \%$ feed refusals.

Feed intakes were determined daily by subtracting the refusal feeds from the offered diet during $24 \mathrm{~h}$. Nutrient digestibility was determined using a total collection method by collecting the feces samples in the last six days of the experiment. The average daily gain was registered weekly.

Table 1 - Chemical composition of feed ingredients used in this study

\begin{tabular}{|c|c|c|c|c|c|c|c|c|}
\hline \multirow{2}{*}{ Ingredients } & \multirow{2}{*}{ DM (\%) } & $\mathrm{EE}$ & CF & Ash & $\mathrm{CP}$ & NFE & OM & $\mathrm{TDN}^{1}$ \\
\hline & & \multicolumn{7}{|c|}{ DM (\%) } \\
\hline Forage & 21.9 & 4.7 & 36.3 & 15.3 & 7.8 & 35.8 & 82.7 & 54.8 \\
\hline Brewer residue & 25.9 & 6.1 & 19.2 & 23.7 & 18.6 & 32.4 & 76.3 & 47.8 \\
\hline Rice bran & 90.5 & 4.8 & 19.8 & 14.7 & 9.9 & 50.7 & 85.3 & 57.8 \\
\hline
\end{tabular}

Note: $\mathrm{DM}=$ dry matter; $\mathrm{EE}=$ ether extract; $\mathrm{CF}=$ crude fiber; $\mathrm{CP}=$ crude protein; $\mathrm{NFE}=$ nitrogen free extract; $\mathrm{OM}=$ organic matter; $\mathrm{TDN}=$ total digestible nutrient. ${ }^{1}$ TDN was calculated according to Hartadi et al. (2003).

Table 2 - Ingredients and nutrient composition of the experimental diets

\begin{tabular}{|c|c|c|c|}
\hline \multirow{2}{*}{ Ingredients } & \multicolumn{3}{|c|}{ Dietary treatments } \\
\hline & $\mathrm{P} 1$ & $\mathrm{P} 2$ & P3 \\
\hline Forage (\%) & 60.0 & 60.0 & 60.0 \\
\hline Brewer residue (\%) & 9.0 & 19.0 & 29.0 \\
\hline Rice bran (\%) & 29.0 & 19.0 & 9.0 \\
\hline Mineral mix (\%) & 2.0 & 2.0 & 2.0 \\
\hline \multicolumn{4}{|l|}{ Nutrient composition } \\
\hline Organic matter (\%) & 81.2 & 80.3 & 79.4 \\
\hline Crude protein (\%) & 9.3 & 10.2 & 11.0 \\
\hline Ether extract (\%) & 4.8 & 4.9 & 5.0 \\
\hline Crude fiber (\%) & 29.3 & 29.2 & 29.2 \\
\hline Ash (\%) & 15.6 & 16.5 & 17.3 \\
\hline Nitrogen free extract (\%) & 41.1 & 39.3 & 37.4 \\
\hline Total digestible nutrient (\%) & 53.9 & 52.9 & 59.5 \\
\hline
\end{tabular}

Note: $\mathrm{P} 1=70 \%$ rice bran $+30 \%$ brewer residue; $\mathrm{P} 2=50 \%$ rice bran $+50 \%$ brewer residue; $\mathrm{P} 3=30 \%$ rice bran $+70 \%$ brewer residue 


\section{Sampling and measurement}

On day 54, fecal samples were collected twice daily and were oven-dried at $55^{\circ} \mathrm{C}$ for 72 hours. The composite with equal dry matter (DM) samples was made to obtain fecal samples for each animal. Following this, the fecal samples were ground through a $1 \mathrm{~mm}$ sieve screen and were analyzed for DM and crude fiber (CF) for nutrient digestibility determination. Determination of the proximate composition [organic matter (OM), DM, ether extract, CF, CP, and ash] was conducted following the AOAC (2005) procedures.

Three animals of each treatment were used for rumen sampling. The rumen fluids were collected using a tube connected to an electric suction and were immediately analyzed for $\mathrm{pH}$ using a digital ph meter (Hanna Model H1-2210, USA). The sampling of rumen fluid was conducted four hours after feeding. The NH3 concentration was determined using spectrophotometry according to Chaney and Marbach (1962), while the Lowry method was used to determine the microbial protein synthesis (Plummer, 1987).

\section{Statistical analysis}

All data obtained in this experiment were subjected to the MIXED procedure analysis in SAS (SAS Studio 3.8, University Edition, 2018) considering the animals as a random factor and dietary treatments as a fixed effect. Means comparison was performed using Duncan multiple range tests (DMRT) posthoc test when $p$ value was less than 0.05 .

\section{Results and discussion}

\section{Nutrient intake}

The nutrient composition of the diets is given in Table 2. Increasing brewer residue proportion to replace the use of rice bran in the diets resulted in higher CP (\%) and TDN content (\%). This result was attributed to the distinct chemical composition of rice bran and brewer residue where the brewer residue was composed of two times higher CP than that of rice bran (18.6 vs $9.90 \%$, respectively).

However, as shown in Table 3, this increasing CP and TDN did not affect DM, CF, CP, and TDN intakes among treatments $(p>0.05)$. DM intakes for all dietary treatments were similar and met the minimum requirement of dry matter intake (DMI) of sheep whereas $\sim 3 \%$ of body weight (BW). This similar DMI indicated positive response of sheep on the dietary brewer residue without refusal. This is also following the general theory that small ruminants could adapt to diets due to their regulatory mechanism to adjust their nutrient need (Hayati et al., 2021; Ribeiro et al., 2021).

Animals would likely refuse feed when it contains a particular substance such as antinutritional compounds in excessive amounts (McDonald et al., 2011). As the brewer residue does not contain any antinutritional factors (Senthilkumar et al., 2010), the inclusion did not impair the DMI. In addition, the brewer residue used in this study had a distinctive aroma that is palatable to sheep in which the texture, color, and smell are similar to rice bran.

\section{Digestibility and growth performance}

This study found a higher DM digestibility following the increase of brewer residue proportion (Table 3). This could be explained by the higher $\mathrm{CP}$ content of brewer residue rather than fiber contents. As shown in Table 2, CP levels of P2 and $\mathrm{P} 3$ were higher than those of P1. Higher dietary CP is beneficial to supply the need of nitrogen source of ruminants since they are often fed with low CP roughages (Astuti et al., 2020).

Brewer residue can be well-digested by sheep because the product corresponds to leftovers from the wheat milling process and had been fermented in the brewing process, increasing the nutrient content, especially in protein (18.62\%). Another plausible reason might be the longer retention time of diets containing brewer residue, as suggested by Doreau et al. (2003). This finding was in agreement with previous experiments reporting that the inclusion of dried brewer residue at $15 \%$ increased DM and OM digestibility (Faccenda et al., 2017). However, the DM digestibility increase in this study was not related to the ADG. Similar ADG recorded in this study was mainly due to the similar nutrient intakes among treatments. Similar results also reported that feeding lambs containing brewer residue did not affect body weight gain (Radzik-Rant et al., 2018, 2019). By contrast, results from other studies suggested that dried brewer inclusion increased daily gain in cattle (Keopaseuth et al., 2017). 
Table 4 summarizes the effects of brewer residue on $\mathrm{pH}, \mathrm{NH}_{3}$, and microbial protein synthesis. Balance of nitrogen and energy supply in the diet plays an essential role to optimize rumen fermentation (Irawan et al., 2021). In the rumen, nitrogen is the main source of microbial protein synthesis, and their balance concentration together with volatile fatty acids production would result in the increase of rumen microbial synthesis (MPS). However, the imbalance between energy and protein would lead to unchanged MPS due to a lack of energy or protein supply (Orskov, 1992).

This was evidenced in this experiment as MPS did not significantly differ among dietary treatments because increasing CP was not supported by increasing soluble carbohydrates.

Table 3 - Nutrient intake, digestibility, and average daily gain of local sheep fed diets containing brewer residue

\begin{tabular}{|c|c|c|c|c|}
\hline \multirow{2}{*}{ Variables } & \multicolumn{3}{|c|}{ Treatments } & \multirow{2}{*}{ p-value } \\
\hline & $\mathrm{P} 1$ & P2 & P3 & \\
\hline DM intake (g/d) & $532.40 \pm 61.00$ & $484.10 \pm 52.00$ & $459.20 \pm 51.00$ & 0.304 \\
\hline CF intake $(\mathrm{g} / \mathrm{d})$ & $152.30 \pm 12.00$ & $155.10 \pm 11.00$ & $145.40 \pm 11.00$ & 0.173 \\
\hline CP intake (g/d) & $49.30 \pm 3.91$ & $49.40 \pm 4.18$ & $50.50 \pm 4.26$ & 0.472 \\
\hline TDN intake (g/d) & $287.30 \pm 23.00$ & $256.40 \pm 22.00$ & $273.40 \pm 23.00$ & 0.274 \\
\hline DM digestibility (\%) & $51.00 \pm 3.72^{b}$ & $56.70 \pm 3.85^{a}$ & $57.80 \pm 4.02^{\mathrm{a}}$ & 0.042 \\
\hline CF digestibility (\%) & $46.10 \pm 3.64$ & $56.70 \pm 3.92$ & $51.80 \pm 3.91$ & 0.109 \\
\hline Aveage daily gain (g/head/d) & $37.50 \pm 2.23$ & $32.50 \pm 2.11$ & $30.00 \pm 1.97$ & 0.102 \\
\hline
\end{tabular}

Note: $\mathrm{P} 1=70 \%$ rice bran $+30 \%$ brewer residue; $\mathrm{P} 2=50 \%$ rice bran $+50 \%$ brewer residue; $\mathrm{P} 3=30 \%$ rice bran $+70 \%$ brewer residue; $\mathrm{DM}=$ dry matter; $C F=$ crude fiber; $C P=$ crude protein; $T D N=$ total digestible nutrient. $a, b$ Different letters indicate significant differences $(p<0.05)$.

Table 4 - $\mathrm{pH}, \mathrm{NH}_{3}$ concentration, and microbial protein synthesis of local sheep fed diets containing brewer residue

\begin{tabular}{lcccc}
\hline \multirow{2}{*}{ Variables } & \multicolumn{3}{c}{ Treatments } & p-value \\
\cline { 2 - 4 } & P1 & P2 & P3 & 0.234 \\
$\mathrm{nH}$ & $6.71 \pm 0.11$ & $6.91 \pm 0.09$ & $6.90 \pm 0.09$ & $<0.002$ \\
$\mathrm{NH}_{3}$ concentration $(\mathrm{mg} / 100 \mathrm{~mL})$ & $6.63 \pm 0.21^{\mathrm{a}}$ & $7.20 \pm 0.24^{\mathrm{a}}$ & $9.30 \pm 0.19^{\mathrm{b}}$ & 0.108 \\
Microbial protein synthesis $(\mathrm{g} / \mathrm{d})$ & $42.40 \pm 5.71$ & $46.30 \pm 4.96$ & $51.80 \pm 6.08$ & \\
\hline
\end{tabular}

Note: $\mathrm{P} 1=70 \%$ rice bran $+30 \%$ brewer residue; $\mathrm{P} 2=50 \%$ rice bran $+50 \%$ brewer residue; $\mathrm{P} 3=30 \%$ rice bran $+70 \%$ brewer residue. a,b Different letters indicate significant differences $(p<0.05)$.

It is shown in Table 2 that fiber content among treatments was similar. As a result, increasing $\mathrm{NH}_{3}$ production occurred in this study and this was not a positive direction because the $\mathrm{NH}_{3}$ would likely be excreted through urine and feces as a potential pollutant. Therefore, it was suggested that increasing dietary CP should be accompanied by appropriate available soluble energy (Irawan et al., 2021).

Microbial protein is a protein fraction synthesized by microbes in the rumen. Rumen microbes use $\mathrm{NH}_{3}$, amino acids, and peptides to synthesize proteins in the microbial body itself. Rumen microbial protein levels are not affected by the ratio of rice bran and beer dregs. The value of microbial protein synthesis ranged from 0.32 to $0.48(\mathrm{mg} / \mathrm{mL})$. The treatments have a complementary relationship between the deficiencies and advantages of each nutrient considering brewer residue as a source of protein and rice bran as a source of carbohydrates. Microbial protein production is highly dependent on the 
breakdown of feed nitrogen, the rate of absorption of $\mathrm{NH}_{3}$ and amino acids, as well as the rate of flow of material out of the rumen. In addition to these factors, another thing that affects the production of microbial protein is the availability of short-chain fatty acids, which are thought to be insufficient to compensate for $\mathrm{NH}_{3}$ to produce microbial protein. Rumen microbes can use more $\mathrm{NH}_{3}$ to synthesize proteins body (Widyawati et al., 2011).

\section{Conclusion}

In conclusion, an increasing proportion of brewer residue to replace rice bran in the diets resulted in the increase of dry matter digestibility in male local sheep, but it is not followed by an increase in performance and microbial protein synthesis. Feeding Indonesian male local sheep with diets containing brewer residue up to $29 \%$ did not negatively affect nutrient intake. Instead, it is promising to reduce feed cost due to the continuous price increase of rice bran.

\section{References}

AOAC. Official methods of analysis of AOAC International. 18th ed. Gaithersburg, MD: Association of Analytical Chemists; 2005.

Astuti D, Suhartanto B, Umami N, Irawan A. Effect of density between intercropped sorghum and stylosanthes on biomass production and quality under varying NPK fertilizer application rates. J Crop Sci Biotechnol. 2020;23(3):197-205.

Chaney AL, Marbach EP. Modified reagent for determination urea and ammonia. Clin Chem. 1962;8:130-2.

Dhiman TR, Bingham HR, Radloff HD. Production response of lactating cows fed dried versus wet brewers' grain in diets with similar dry matter content. J Dairy Sci. 2003;86(9):2914-21.

Doreau M, Michalet-Doreau B, Grimaud P, Atti N, Nozière P. Consequences of underfeeding on digestion and absorption in sheep. Small Rumin Res. 2003;49(3):289-301.

Faccenda A, Zambom MA, Castagnara DD, Avila AS, Fernandes T, Eckstein El, et al. Use of dried brewers' grains instead of soybean meal to feed lactating cows. Rev Bras Zootec. 2017;46(1):39-46.

Hartadi H, Reksohadiprodjo S, Tillman AD. Tabel Komposisi Pakan Untuk Indonesia. 3rd ed. Yogyakarta: Gadjah Mada University Press; 2003.
Hayati RN, Panjono P, Irawan A. Estrous signs and progesterone profile of ongole grade cows synchronized at different ages fed different level of dietary crude protein. Trop Anim Sci J. 2021;44(1):16-23.

Irawan A, Noviandi CT, Kustantinah, Widyobroto BP, Astuti A, Ates $\mathrm{S}$. Effect of Leucaena leucocephala and corn oil on ruminal fermentation, methane production, and fatty acid profile: an in vitro study. Anim Prod Sci. 2021;61(5):459-69.

Keopaseuth T, Preston TR, Tham HT. Cassava (Manihot esculenta Cranz) foliage replacing brewer's grains as a protein supplement for Yellow cattle fed cassava pulp-urea and rice straw; effects on growth, feed conversion, and methane emissions. Livest Res Rural Dev. 2017;29(2).

McDonald P, Edwards RA, Greenhalgh JFD, Morgan CA, Sinclair LA, Wilkinson RG. Animal Nutrition. Harlow: Pearson; 2011.

Orskov ER. Protein Nutrition in Ruminant. London: Academic Press; 1992.

Plummer DT. An introduction practical laboratory. New Delhi: McGraw-Hill Book Company LTD; 1987.

Radzik-Rant A, Rant W, Niznikowski R, Światek M, Szymańska Z, Ślęzak $M$, et al. The effect of the addition of wet brewers grain to the diet of lambs on body weight gain, slaughter valueand meat quality. Arch Anim Breed. 2018;61(2):245-51.

Radzik-Rant A, Rant W, Niznikowski R, Światek M, Szymańska Z, Ślęzak $M$, et al. The effect of the brewing and milling by-products containing in the lambs diet on body weight growth, slaughter value and meat quality. Anim Sci. 2019;58(2):169-79.

Ribeiro DR, Ratim JLS, Ribeiro KM, Almeida R, Ostrensky A, Anater $A$, et al. Productive evaluation of dairy cows fed with urea protected by protein nanoparticle in partial replacement of soybean meal. Rev Acad Cienc Anim. 2021;19:e19007.

Senthilkumar S, Viswanathan TV, Mercy AD, Gangadevi P, Ally K, Shyama K. Chemical Composition of Brewery waste. Talmilnadu J Vet Anim Sci. 2010;6(1) 49-51.

Widyawati SD, Suprayogi WPS, Utomo R, Budhi SPS. Percepatan Penggemukkan Ternak Sapi Melalui suplementasi Sumber Protein degan Metode Slow-Released-Ammonia [reseaech report]. Surakarta:, Indonesia: Universitas Sebelas Maret; 2011.

Younker RS, Winland SD, Firkins JL, Hull BL. Effects of replacing forage fiber or nonfiber carbohydrates with dried brewers grains. J Dairy Sci. 1998;81(10): 2645-56. 